\title{
Correction to: Elevated microRNA-129-5p level ameliorates neuroinflammation and blood-spinal cord barrier damage after ischemia-reperfusion by inhibiting HMGB1 and the TLR3-cytokine pathway
}

Xiao-Qian Li@, Feng-Shou Chen, Wen-Fei Tan, Bo Fang, Zai-Li Zhang and Hong Ma*

\section{Correction to: J Neuroinflamm (2017) 14:205}

https://doi.org/10.1186/s12974-017-0977-4

The original version of the article [1] unfortunately contained a mistake. The error occurred in representative images of double immunofluorescence of Fig. 6.
The other data and the conclusion in the publication are real and reliable.

It has been corrected in this correction.

The correct version of Fig. 6 is given in this Correction article. original author(s) and the source, provide a link to the Creative Commons licence, and indicate if changes were made. The images or other third party material in this article are included in the article's Creative Commons licence, unless indicated otherwise in a credit line to the material. If material is not included in the article's Creative Commons licence and your intended use is not permitted by statutory regulation or exceeds the permitted use, you will need to obtain permission directly from the copyright holder. To view a copy of this licence, visit http://creativecommons.org/licenses/by/4.0/. The Creative Commons Public Domain Dedication waiver (http://creativecommons.org/publicdomain/zero/1.0/) applies to the data made available in this article, unless otherwise stated in a credit line to the data. 


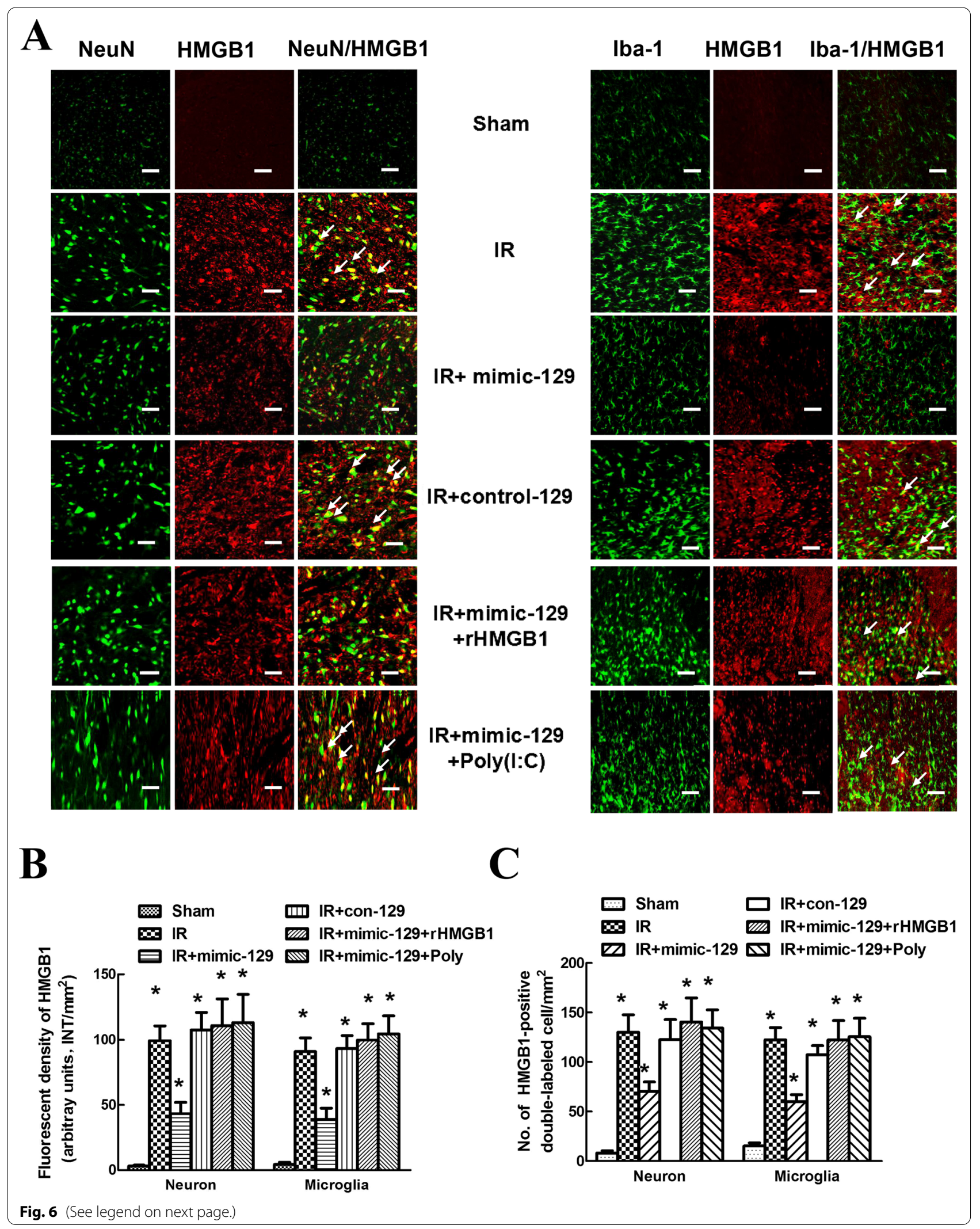


(See figure on previous page.)

Fig. 6 Effects of the miR-129-5p mimic and mimic control on HMGB1 expression in specific cell types of the spinal cord after IR. a Representative photomicrographs showing the localization of the fluorescence signals for HMGB1 in neurons and microglia at $48 \mathrm{~h}$ after IR. Arrows indicate co-localization. Scale bars $=50 \mu \mathrm{m}$. $\mathbf{b}$ Quantification of HMGB1 signals was performed based on the average of three independent images. $\mathbf{c}$ Quantification of HMGB1-positive neurons and microglia in the spinal cords at $48 \mathrm{~h}$ after IR. Data are expressed as the mean $\pm S D$. ${ }^{*} P<0.05$ versus the Sham group. ${ }^{\sharp} P<0.05$ versus the IR group

Published online: 28 December 2021

\section{Reference}

1. Li X-Q, Chen F-S, Tan W-F, Fang Bo, Zhang Z-L, Ma H. Elevated microRNA129-5p level ameliorates neuroinflammation and blood-spinal cord

barrier damage after ischemia-reperfusion by inhibiting HMGB1 and the TLR3-cytokine pathway. J Neuroinflamm. 2017;14:205. https://doi.org/10. 1186/s12974-017-0977-4.

\section{Publisher's Note}

Springer Nature remains neutral with regard to jurisdictional claims in published maps and institutional affiliations. 